\title{
Matching Nutrient Requirements to Hay Produced in Tennessee: A Modeling Study
}

\author{
Brian T. Campbell ${ }^{1}$, John C. Waller ${ }^{2}$, William M. Backus ${ }^{3}$, Arnold M. Saxton ${ }^{2} \&$ Deborah K. Joines $^{4}$ \\ ${ }^{1}$ Virginia Tech Southern Piedmont AREC, Blackstone, VA, USA \\ ${ }^{2}$ Department of Animal Science, The University of Tennessee, Knoxville, TN, USA \\ ${ }^{3}$ Research and Extension Center at Ames Plantation, The University of Tennessee, Grand Junction, TN, USA \\ ${ }^{4}$ The Tennessee Soil, Plan, and Pest Center, Nashville, TN, USA \\ Correspondence: Brian T. Campbell, Virginia Tech Southern Piedmont AREC, Blackstone, VA, USA. E-mail: \\ brian3@vt.edu
}

$\begin{aligned} & \text { Received: November 10, } 2014 \quad \text { Accepted: December 12, } 2014 \quad \text { Online Published: April 15, } 2015 \\ & \text { doi:10.5539/jas.v7n5p1 }\end{aligned}$ URL: http://dx.doi.org/10.5539/jas.v7n5p1

\begin{abstract}
Winter hay feeding is generally the most expensive cost of maintaining a cow for the year. Because of this it is beneficial for a producer to maximize the use of their hay supply. A modeling study was completed that compared the nutrient requirements of three fall calving herds and three spring calving herds to determine differences in nutrient requirements between the herds. Hay feeding should be tailored to the operation and the calving season for the most efficient use of hay.
\end{abstract}

Keywords: winter feed, hay, cattle, calving season

\section{Introduction}

Tennessee's beef cow herd of approximately 1,000,000 cows grazing approximately 3 million hectares of Tall Fescue (Lolium Arundinacea) throughout the year. When the forage does not meet the requirements of these cows due to dormancy or low quality, hay or supplemental nutrients must be supplied. Hay is the most prevalent and least expensive way to supplement cattle during the winter months. Winter hay feeding generally lasts from mid-November to mid to late-march.

Beef cattle production in Tennessee is primarily cow/calf operations (Waller et al., 2013). The traditional calving season is a spring calving season beginning in mid-January and ending in mid-March. Some producers maintain a fall calving herd, and the fall calving cows will begin calving in mid-September and calve through mid-November.

Feed is the most expensive component of raising any animal and for beef cattle winter is generally when the majority of supplemental feed is provided to the animals (Waller et al., 2013). With this in mind most farmers are interested in lowering the cost of winter feeding (Volesky et al., 2002). The hay feeding period generally runs from when the supply of stockpiled tall fescue has been depleted until April when the spring growth begins. Nutrient requirements of cows change depending on the size of the cow, the milk production of the cow and the stage of production. A computer model was developed to estimate the requirements of cows in 6 herds (3 fall calving and 3 spring calving) to determine the percentages of Tennessee hay that met the requirements for the herds.Because of the time of year when hay is produced and the weather conditions that exist in the south east at that time making high quality hay is often a challenge due to weather and the time needed for hay to properly dry in the field.. The objective of this study was to compare the nutrient composition of hays produced in Tennessee and their ability to meet the nutrient requirements of beef cattle during the winter.

\section{Materials and Methods}

Forage samples were obtained from the Tennessee forage testing laboratory in Nashville, TN. Samples used were [bermudagrass (Cynodon dactylon) - 392; tall fescue (Lolium arundinacea) - 607; grass/clover - 200; mixed grass - 793; and orchardgrass (Dactylis glomerata) - 84] for the analysis (Table 1). 
Table 1. Type of hay, number of samples and the average nutrient content of the samples

\begin{tabular}{llll}
\hline Hay Type & Number of Samples & $\mathbf{\%} \mathbf{~ T D N}^{\mathbf{1}}$ & $\mathbf{\%} \mathbf{C P}^{\mathbf{2}}$ \\
\hline Bermudagrass & 392 & 62.8 & 12.4 \\
Fescue & 607 & 62.8 & 12.0 \\
Grass/Clover & 200 & 63.7 & 14.4 \\
Mixed Grass & 793 & 59.36 & 13.2 \\
Orchardgrass & 84 & 59 & 12.2 \\
Total & 2076 & & \\
\hline
\end{tabular}

Note. ${ }^{1} \mathrm{TDN}=$ Total digestible nutrients; ${ }^{2} \mathrm{CP}=$ Crude protein.

These forage samples were submitted from Jan. of 2007 - Dec. 2009. They were analyzed for CP and TDN using NIR spectroscopy. The cow herds were modeled based on herd records from the Ames Plantation herds. The calving distribution was determined from eight years of data and was modeled on a 60-d calving season. The spring calving season began Feb. $1^{\text {st }}$ and ended April $1^{\text {st }}$ and the fall calving season began Oct. $1^{\text {st }}$ and ended Dec. $1^{\text {st }}$. The herds were modeled as three different size herds based on average mature weight a small, medium, and large herd being $454 \pm 45 \mathrm{~kg}, 544 \pm 45 \mathrm{~kg}$, and $635 \pm 45 \mathrm{~kg}$ respectively. Milking ability was modeled for each herd with an average of $9 \mathrm{~kg} \pm 4.5 \mathrm{~kg}$ and ranged from 4.5 to $14.5 \mathrm{~kg}$.

The distribution of calving dates was obtained from herd records maintained for the research and education center at Ames Plantation. Six cow herds were modeled in this study. The herds were three spring and three fall calving beef herds. The herds were based on mature weight of the animal and had an average of 453.6, 544.3, and $635.0 \mathrm{~kg} \pm 45.4 \mathrm{~kg}$ respectively and an average milk production of $9.1 \mathrm{~kg} \pm 4.5 \mathrm{~kg}$. A $60 \mathrm{~d}$ calving season was modeled, with fall calving starting on October first and a spring calving season starting February first. Data were analyzed using SAS 9.2 in a system that checked each hay sample as to when it would meet the cow's requirements. For a herd averaging $544.3 \mathrm{~kg}$ tall fescue hay will meet the requirements of $80 \%$ of the cows between 56 and $85 \%$ of the time depending on their calving date. The requirements of fall calving cows will decrease during the winter feeding period while the requirements of the spring calving cows will increase.

Hay feeding was modeled to begin on Nov. 15 and ended Mar. 15. All hays were compared with individual cow requirements in each $10 \mathrm{~d}$ period. Tall fescue comparisons are presented because this is the predominant hay fed in Tennessee and the mid-south United States. The amount of hay that needed to be fed was based on published dry matter intake estimates.

Data were analyzed using SAS 9.2 (Cary, NC). The data were analyzed as a completely random design using the Mixed Model analysis of variance. This was used to make the comparison of each hay sample with each cow for all periods. Each hay sample was compared to each cow for CP and TDN resulting in over 12 million comparisons.

\section{Results and Discussion}

The forage samples are expected to be the higher quality hay samples that are produced in the state, due to better producers being the ones that will submit hay samples for testing. There was more variation with in forage species than there was between species suggesting that it does not matter what forage type is used as long as it is produced well.

The spring calving herd requirements for quality increased during the period of winter feeding with a dramatic increase at calving (Figure 1). 


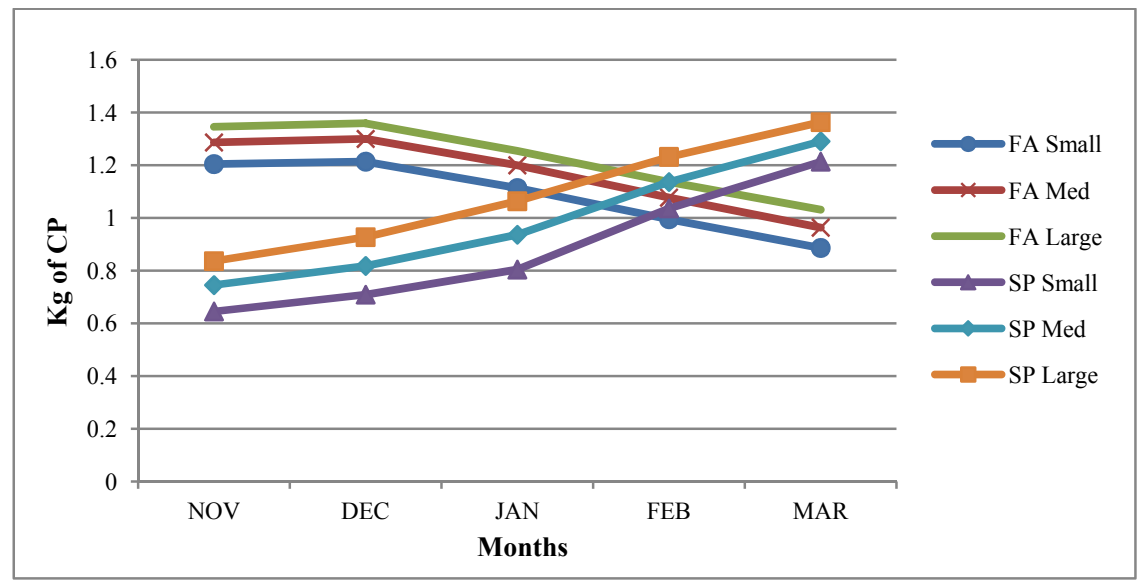

Figure 1. Kilograms of protein required per cow per day during winter feeding

In the month of November for the herd averaging $543 \mathrm{~kg}, 99 \%$ of the tall fescue samples met the requirements for $\mathrm{CP}$ and $93 \%$ met the requirements for TDN for $80 \%$ of the herd (Figure 2).

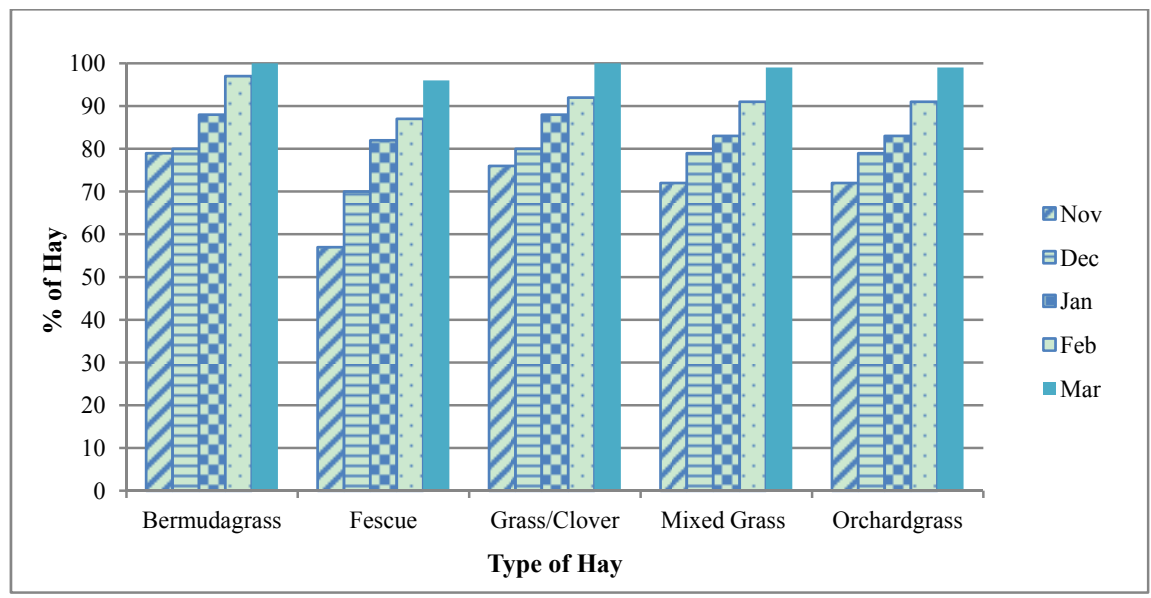

Figure 2. Percentage of hay that meets the TDN requirements of a $636 \mathrm{~kg}$ cow milking $9.1 \mathrm{~kg} / \mathrm{day}$

This is due to the relatively low metabolic needs of a dry gestating mature cow. In March only $57 \%$ and $28 \%$ of the samples met the requirements for $\mathrm{CP}$ and TDN of $80 \%$ of the herd respectively. There is a dramatic increase in the nutrient requirements of the cows at calving. As milk production peaks the nutrients required are greatest and the fewest hays will meet the requirements of the cow. For producers with spring calving cows this would mean they should feed their poorest quality hay first and feed higher quality hay when the demand for nutrients is greater.

The fall calving herd, which is the less prevalent management plan in Tennessee, requires higher nutrient quality hay at the beginning of the winter period. In November only $65 \%$ of hay samples met CP requirements and $27 \%$ of the hay met the TDN requirements for $80 \%$ of the herd. These cows have recently calved and are milking heavily. In March $89 \%$ of the hay met the requirement for CP and $74 \%$ met the requirement for TDN for $80 \%$ of the herd. Milk production in a fall calving herd is decreasing throughout the winter feeding period because of this producers with a fall calving herd should feed their highest quality hay first.

When nutrients are compared on a per head basis there were several facts that became apparent. Cow size has an impact on the amount of feed that is required, but also on the quality of feed that must be provided. A larger cow can have its nutrient requirements met by poorer quality hay due to a higher level of consumption. Smaller cows while they do eat less require a higher quality feed to meet their nutrient requirements.

When cows were compared across sizes and levels of milk productions it became apparent that levels of milk production had a larger impact on nutrients required than did the size of the cow. So if nutrients and feed 
resources are a limiting factor for a beef operation it is better to select for cows with a lower milk production level rather than for smaller framed cows.

\section{Conclusions}

It is believed that these samples represent the highest quality hay being produced in Tennessee as the lower quality hay is not tested. This means that forages are cut, dried, baled, and called hay. When nutrient analysis is done on these hays they are more closely resemble straw than hay. Much of this is due to weather and the ability to cut and bale hay at the correct stage of maturity without rain fall. Most of the herds in Tennessee would benefit from a supplementation during their peak lactation, and because Tall Fescue is the primary forage an energy supplement rather than a protein supplement would be the best option for supplementation, and it is important to remember that milk production, not size has the greatest impact on the nutrient requirements of cattle.

\section{References}

NRC. (1996). Nutrient Requirement of Beef Cattle (7th ed.). National Research Council. Nat. Acad. Sci., Washington, DC.

Garrand, R. M., \& Glaze, J. B. Jr. (2008). Supplement Allows Ranchers to Eliminate Hay Feeding and Reduce Winter Feed Costs. Journal of Extension, 46(3), Article 3IAW6. Retrieved from http://www.joe.org/joe/2008june/iw6.php

Volesky, J. D., Adams, D. C., \& Clark, R. T. (2002). Windrow grazing and baled-hay feeding strategies for wintering calves. J. Range Management, 55(1). http://dx.doi.org/10.2307/4003259

Waller, J. C., Fisher, A. E., Bates, G. E., Schrick, F. N., \& Campbell, B. T. (2013). Tall Fescue Based Forage Systems Supplemented with Winter Annuals for Stocker Cattle. Journal of Agriculture Science, 1, 61-66.

\section{Copyrights}

Copyright for this article is retained by the author(s), with first publication rights granted to the journal.

This is an open-access article distributed under the terms and conditions of the Creative Commons Attribution license (http://creativecommons.org/licenses/by/3.0/). 